\title{
REVIEW OF RESEARCH TRENDS IN WATERSHED-BASED LAND USE ANALYSIS
}

\author{
Luong LIM $^{1}$ and Yoh SASAKI ${ }^{2}$ \\ ${ }^{1}$ Non-member of JSCE, Dept. of Civil and Environmental Eng., Waseda University \\ (3-4-1 Okubo, Shinjuku-ku, Tokyo 169-8555 Japan) \\ E-mail: luong@moegi.waseda.jp \\ ${ }^{2}$ Member of JSCE, Professor, Dept. of Civil and Environmental Eng., Waseda University \\ (3-4-1 Okubo, Shinjuku-ku, Tokyo 169-8555 Japan) \\ E-mail: yoh@waseda.jp
}

\begin{abstract}
With increased awareness of the importance of land use change at both local and regional scales within watershed-based planning, the study of land use analysis has become the focus of several international scientific endeavors. Since land use change has become a major issue in this century due to global urbanization, the study of watershed-based land use analysis will play an important role in a sustainable future. This paper undertakes a comprehensive review of watershed-based land use analysis to clarify the research trends in this area, including basic tools, factors, methodologies, study regions, scales and areas. Land use detection methods, land use modeling and thresholds in watershed delineation were identified as the fundamental tools, while land use policies, water quality, surface runoff, flooding control, land use suitability and land allocation analysis, and landscape structure were identified as the main factors in watershed-based land use planning.
\end{abstract}

Key Words: land use analysis, watershed, local and regional scale, watershed-based land use planning

\section{INTRODUCTION}

Land use change is a major issue for this century, and urbanization is considered to be one of the dominant forms of land use change in terms of increasing surface runoff, impervious cover, and non-point source (NPS) pollution, which are accompanied by water pollution components ${ }^{1), 2}$. Consequently, it causes urban flooding and degradation of water quality and the natural environment, leading to further changes in land use patterns.

Watershed-level planning is inherently concerned with land use issues and their impact on watershed interests, such as stream quality and biological diversity. Watersheds have been used as physical, biological, social, economic, and political units for the planning and implementation of land management activities $^{3)}$. In the United States, the use of watersheds as planning units originated from defining the best hydrological planning units for land, water, and ecosystem management, then defining governmental boundaries based on watersheds, and finally delineating the boundaries of district planning based on watersheds $^{4}$. For example, in New York, a watershed management agreement was signed in 1997 to protect the quality of drinking water while promoting environmental sustainability compatible with economic development ${ }^{5)}$. Japan has based planning for ecosystems, cultural landscapes, and disaster prevention on the watershed unit; it has also introduced watershed-based planning in the master plans for parks and open space in some municipalities ${ }^{6}$. Therefore, for city and regional planning, the watershed can be considered as a reference even though its boundaries do not necessarily coincide with the administrative boundaries.

In watershed-based research, the study of land use is considered to be one of the most prominent issues. Many studies have focused on the influences and impacts of land use practices due to urban development, which have a major impact on the natural environment and consequentially on the watershed. These studies have been discussed widely in the fields of hydrology, water resource management, environmental management, agriculture, geography, geology, land use, landscape, green space, and disaster prevention planning. They differ in their purposes, methodologies, available data, and applications, since the nature of land use analysis is dependent on many driving forces, especially the in- 
teraction between human activities and natural resources. Therefore, this multifaceted issue requires a multidisciplinary approach to resolve its associated problems, which are introduced in this paper.

As the rate of global urbanization is constantly increasing, and the study of watershed-based land use analysis is broad and deals with complicated issues, it is essential to clarify research trends in this realm. Therefore, the aim of this paper is to: (1) identify the research trends of basic tools, and (2) identify the research trends of the factors, methodologies, study regions, scales and areas, and the relationship of these factors in watershed-based land use analysis, which can be used for better future planning and research.

\section{RESEARCH METHODOLOGIES AND PROCESS}

(1) Definition of catchment, sub-watershed, watershed, river basin, and drainage area

A catchment is a land area where all surface water (rain, melting snow or ice) drains into a common outlet, while a sub-watershed is composed of two or more catchments; a watershed is composed of many catchments and sub-watersheds.

The term 'river basin' is defined as an area of land drained by a river or its tributaries.

A drainage area is the total surface area, upstream of an outlet of a stream, where water from rain, snowmelt, ice or irrigation not absorbed into the ground flows over the ground surface and back into streams, and finally flows into the outlet.

\section{(2) Selection of target academic papers}

In the selection process for the academic papers targeted in this study, we used web search engines and publishers' websites, input keywords, and criteria for selecting target academic papers.

The selection process for target academic papers is shown in Fig. 1. First, 15 combinations of two keyword terms were inputted into web search engines and publishers' websites based on the criteria shown. The obtained watershed-based papers were concerned mainly with three fields: landscape, ecological environment, and land use, with dates ranging from 1977 to 2015. Second, the target papers were filtered and selected for the studies related to watershed-based land use analysis, excluding the two other fields. The dates of the resulting papers ranged from 1991 to 2015, as shown in Table 1. These papers come from international journals and conference papers and various academic journal publishers. These publishers covered almost the whole globe including Europe, Asia, and North America, which shows that various publishers were involved in the academic paper selection process. The study regions were mainly defined according to the continents; these studies have been carried out in Asia, Europe, North America, South America, Africa, Australia, and Oceania.

\section{(3) Historical review of the target academic papers}

Watershed-based studies, which have received far more attention within the biological and physical sciences than the social science framework, have long been used by researchers in landscape as well as ecological and environmental management studies.

Once filtered, the dates of the selected papers began in 1991. Watershed-based land use analysis became prominent during the 1990s, when many watershed geographical information (GIS) applications were developed ${ }^{7)}$ and growing concerns about

\begin{tabular}{|c|c|}
\hline \multicolumn{2}{|c|}{$\begin{array}{l}\text { Google Scholar, Scopus, Web of Science, J-Stage } \\
\text { Publishers: } \\
\text { ScienceDirect, ASCE library, Wiley Online Library }\end{array}$} \\
\hline \multicolumn{2}{|l|}{$\nabla$} \\
\hline \multicolumn{2}{|c|}{$\begin{array}{l}\text { Input two keyword terms in the web search engine }=a_{i} b_{j} \\
(0<i \leq 5 ; 0<j \leq 3)\end{array}$} \\
\hline $\begin{array}{l}\mathrm{a}_{1} . \text { Land use } \\
\mathrm{a}_{2} \text {. Land use analysis } \\
\mathrm{a}_{3} \text {. Land use planning } \\
\mathrm{a}_{4} \text {. Land use change } \\
\mathrm{a}_{5} \text {. Land cover }\end{array}$ & $\begin{array}{l}\mathrm{b}_{1} \text {. Based on watershed } \\
\mathrm{b}_{2} \text {. At a watershed scale } \\
\mathrm{b}_{3} \text {. At watershed level } \\
\text { planning }\end{array}$ \\
\hline Note: No limitation $t$ & blishing year \\
\hline
\end{tabular}

Criteria for academic paper selection

1. Based on the background of each academic paper relating to the issues of urban development, urban expansion, urbanization and its associated influences, impacts and consequences in terms of various research fields.

2. Selecting the related papers in the references of each academic paper in 1 .

Selection of academic papers

Around 70 academic papers including landscape, environmental ecology and land use, which are based on watersheds, were identified, with the publishing years ranging from 1977 to 2015 .

Criteria for target academic papers selection

Filtered and selected for papers mainly related to watershed-based land use analysis 55/70

Note: 15 of the 70 papers are not referred to in the references.

Fig.1 Target academic paper selection process. 
urban development's effects on the natural environment began prompting efforts to find more sustainable solutions to the problems arising from the built environment.

\section{(4) Contents of this study}

Section 3 examines the general trends in the target academic papers. All target academic papers were categorized based on publisher, characteristics of study regions, and research fields.

Section 4 covers research trends in the basic tools applied in watershed-based land use analysis. This section discusses basic tools including land use detection methods, land use modeling and thresholds in the watershed delineation process.

Section 5 discusses research trends in the factors used in watershed-based land use analysis. In this section, target academic papers were summarized based on background, purpose, target watershed scale, data type, methodology, findings, limitations, and future research. These factors were identified based on the research purposes of each summarized paper and then grouped in order to clarify method- ologies, study region, area, scale, and the relationship of these factors in watershed-based land use analysis in different research fields.

\section{GENERAL TRENDS IN THE TARGET ACADEMIC PAPERS}

A total of 55 target academic papers were categorized according to publisher, characteristics of the study region, research field and journal name, with the publishing year of each target academic paper, as shown in Figs. 2, 3, and $\mathbf{4}$ respectively.

Among the target academic papers, as shown in Fig. 4, four main research fields were defined: (1) environment and management, (2) hydrology, (3) planning and development, and (4) remote sensing, GIS applications, and others. Figures $\mathbf{2}$ and $\mathbf{3}$ show trends in the study regions and publishing years. Before 2002, few papers were defined in Asia; however, from 2003 a fluctuation in the number of studies seems to have taken place in Asia.

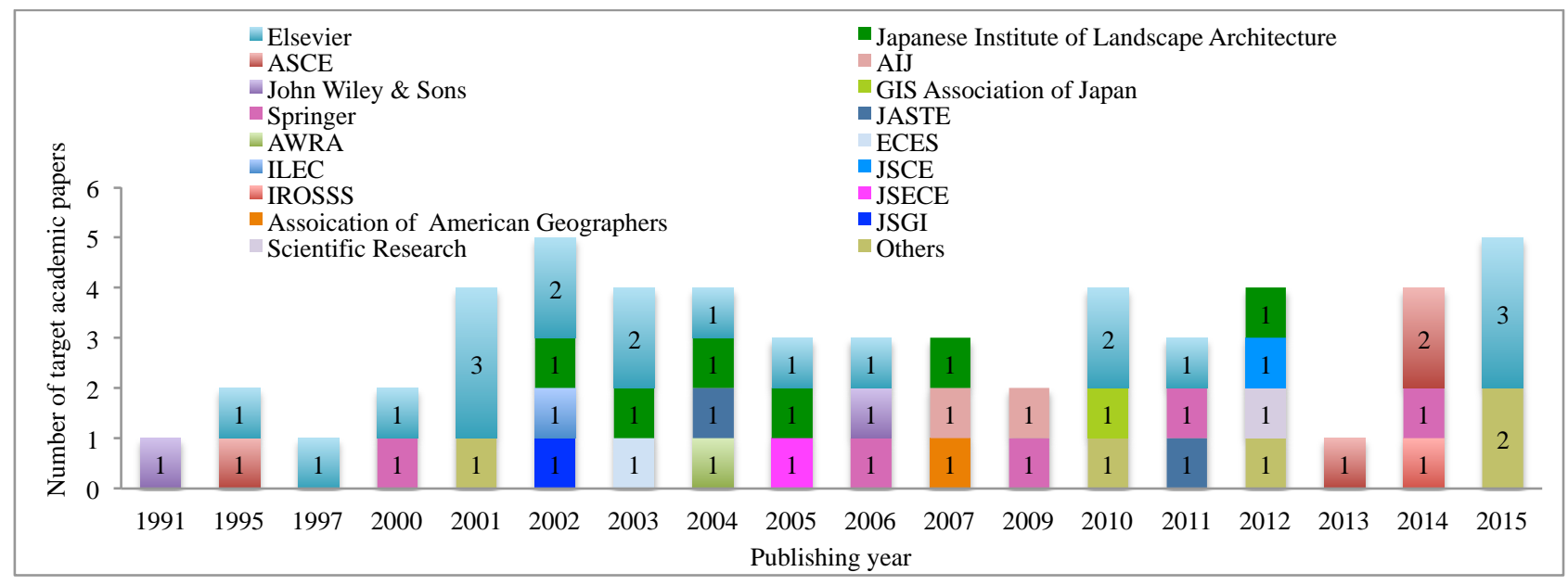

Fig.2 Publishers and publishing year of target academic papers.

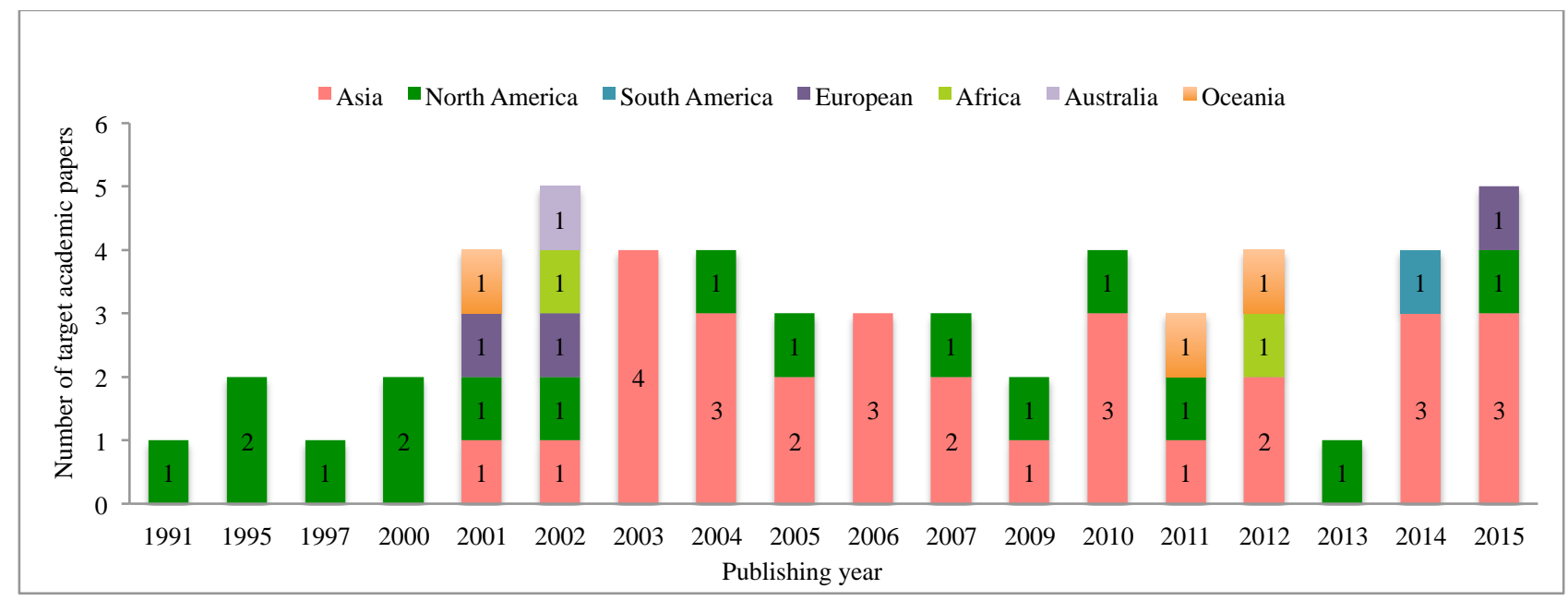

Fig.3 Study region and publishing year of target academic papers. 
Table 1 Publisher and journal name of target academic papers.

\begin{tabular}{|c|c|}
\hline Publishers & Journal name (total papers) (publishing year of target academic paper) \\
\hline Elsevier & $\begin{array}{l}\text { Agriculture, Ecosystems and Environment (2) }(2001 ; 2003) \\
\text { CATENA (1) (2003) } \\
\text { Computers \& Geosciences (1) (2010) } \\
\text { Environment International (1) (1997) } \\
\text { Journal of Environmental Management (2) }(2001 ; 2005) \\
\text { Journal of Hydrology (1) (2002) } \\
\text { Land Use Policy (1) (1995) } \\
\text { Landscape and Urban Planning (6) (2000-2015) } \\
\text { Physics and Chemistry of the Earth (1) (2001) } \\
\text { Procedia Environmental Sciences (1) (2011) } \\
\text { Science of the Total Environment (1) (2015) } \\
\text { The Egyptian Journal of Remote Sensing and Space Sciences (1) (2015) }\end{array}$ \\
\hline John Wiley \& Sons & Hydrological Processes $(2)(1991 ; 2006)$ \\
\hline Springer & $\begin{array}{l}\text { Environmental Management (2) (2000; 2009) } \\
\text { Environmental Monitoring and Assessment (2) (2006; 2011) } \\
\text { Sustainability Science (1) (2014) }\end{array}$ \\
\hline $\begin{array}{l}\text { American Society of Civil } \\
\text { Engineering (ASCE) }\end{array}$ & $\begin{array}{l}\text { Journal of Hydrologic Engineering (1) (2013) } \\
\text { Journal of Urban Planning and Development (2) (2014) } \\
\text { Journal of Water Resources Planning and Management (1) (1995) }\end{array}$ \\
\hline $\begin{array}{l}\text { American Water Resource } \\
\text { Association (AWRA) }\end{array}$ & Journal of the American Water Resource Association (JAWRA) (1) (2004) \\
\hline $\begin{array}{l}\text { Association of American Ge- } \\
\text { ographers }\end{array}$ & Middle States Geographer (1) (2007) \\
\hline $\begin{array}{l}\text { Japan Society of Civil Engi- } \\
\text { neering (JSCE) }\end{array}$ & $\begin{array}{l}\text { Journal of Japan Society of Civil Engineers, Ser. B1 (Hydraulic Engineering) (1) } \\
\text { (2012) }\end{array}$ \\
\hline $\begin{array}{l}\text { Japanese Institute of Land- } \\
\text { scape Architecture }\end{array}$ & Journal of The Japanese Institute of Landscape Architecture (6) $(2002 ; 2012)$ \\
\hline $\begin{array}{l}\text { Architecture Institute of Japan } \\
(\mathrm{AIJ})\end{array}$ & Journal of Architecture and Planning (2) $(2007 ; 2009)$ \\
\hline $\begin{array}{l}\text { Ecology and Civil Engineer- } \\
\text { ing (ECES) }\end{array}$ & Ecology and Civil Engineering (1) (2003) \\
\hline GIS Association of Japan & Theory and Applications of GIS (1) (2010) \\
\hline $\begin{array}{l}\text { Japan Society of Erosion Con- } \\
\text { trol Engineering (JSECE) }\end{array}$ & Journal of the Japan Society of Erosion Control Engineering (1) (2005) \\
\hline $\begin{array}{l}\text { Japan Society of Tropical } \\
\text { Ecology (JASTE) }\end{array}$ & Tropics (2) $(2004 ; 2011)$ \\
\hline $\begin{array}{l}\text { Scientific Research, Interna- } \\
\text { tional Lake Environment } \\
\text { Committee Foundation (ILEC) }\end{array}$ & Journal of Lakes \& Reservoirs: Research and Management (1) (2002) \\
\hline $\begin{array}{l}\text { International Research Opera- } \\
\text { tion in Sciences \& Social Sci- } \\
\text { ences (IROSSS) }\end{array}$ & $\begin{array}{l}\text { International Journal of Advancement in Remote Sensing, GIS and Geography (1) } \\
\text { (2014) }\end{array}$ \\
\hline $\begin{array}{l}\text { Japan Society of Geoinformat- } \\
\text { ics (JSGI) }\end{array}$ & Geoinformatics (1) (2002) \\
\hline Scientific Research & Journal of Geographic Information System (1) (2012) \\
\hline Others & $\begin{array}{l}\text { Asia Conference of Remote Sensing (1) (2010) } \\
\text { The International Symposium on Cartography in Internet and Ubiquitous Environ- } \\
\text { ments (1) (2015) } \\
\text { Environmental Design Research (1) (2012) } \\
\text { The } 15^{\text {th }} \text { Science Council of Asia Conference and International Symposium (1) } \\
(2015) \\
\text { World Water and Environmental Resources Congress (1) (2001) }\end{array}$ \\
\hline
\end{tabular}




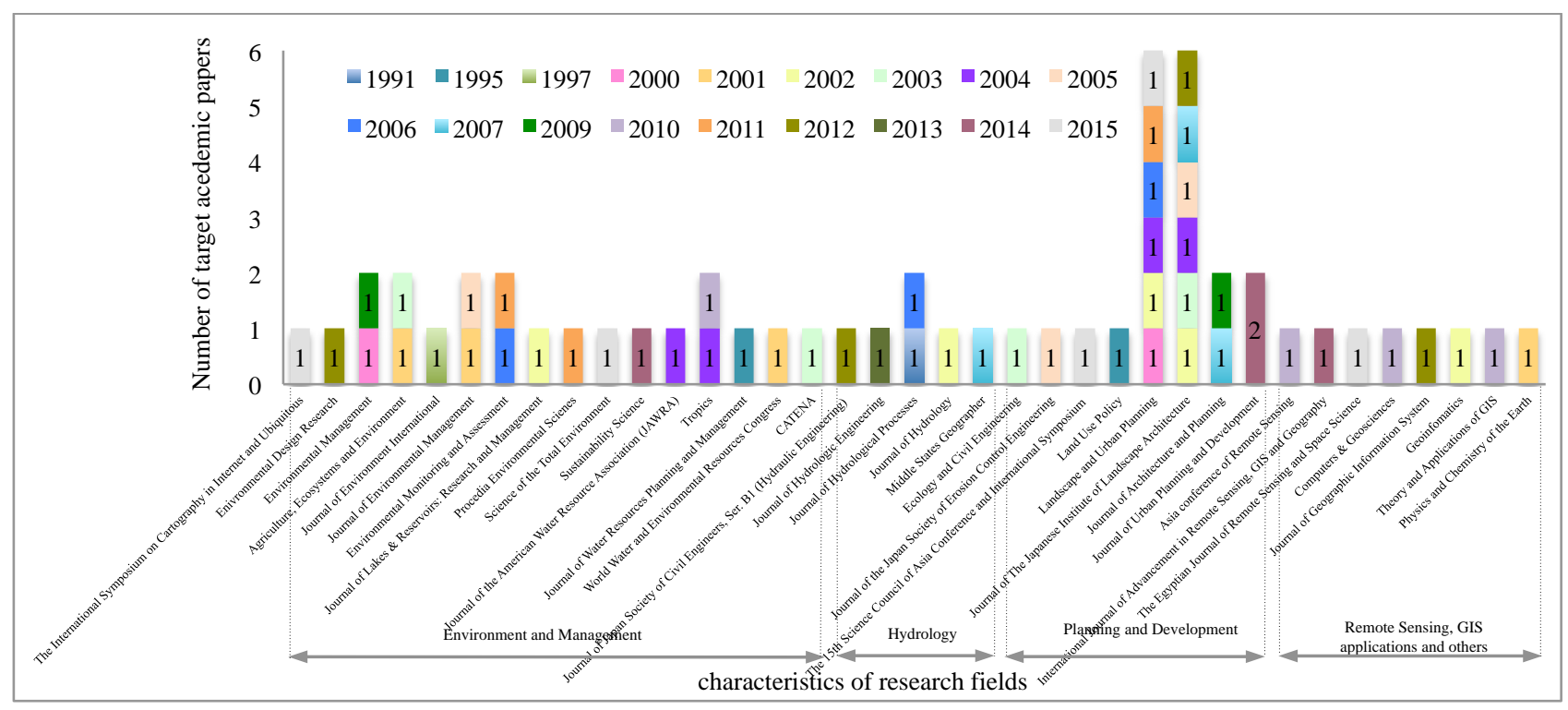

Fig.4 Characteristics of research fields and publishing year of target academic papers.

\section{RESEARCH TRENDS IN BASIC TOOLS}

In the study of watershed-based land use analysis, land use detection methods, land use modeling, and watershed delineation methods are considered basic tools, and are applied widely by researchers using watersheds as the planning unit.

\section{(1) Trends in watershed-based land use detection and modeling}

The progressive worsening of urban environments, and the destruction of ecosystems due to the rapid pace of urban development, have led to awareness of the important role of land use and land cover in overcoming those problems ${ }^{8)}$. Therefore, it is essential to understand the trends related to the study of land use applied at the watershed scale. Among the 55 target academic papers, watershedbased land use analysis has been carried out in two forms: land use detection methods and land use modeling.

\section{a) Trends in watershed-based land use detection methods}

Rapid development of computer technology makes it possible for both scientific communities and scholars to make use of databases such as Quickbird, RapidEye and Landsat, which provide data at very high, high, and medium spatial resolution, respectively. These databases are used to carry out land use and land cover analysis with the integration of geographical information systems for understanding and defining land use and land cover dynamics ${ }^{9}$, understanding land use change, and predicting land use in the future ${ }^{10)}$. Many studies have shown that studies of land use detection have made extensive use of satellite imaging such as the Landsat Multispectral Scanner System (MSS) and
Landsat Thematic Mapper (TM), with remote sensing software ERDAS IMAGINE ${ }^{9), 10), 11), 12), 13), ~ 14), ~ 15), ~}$ while a few studies also applied image-processing software IDRISI ${ }^{16)}$ and Geographical Information System (GIS) with image processing ${ }^{17), 18)}$ for the detection of land use through Landsat data with six important steps in image classification ${ }^{19)}$. However, in detecting land use using remote sensing data, there are some shortcomings for tropical areas, where the cloud cover is high. Some studies have developed a method to overcome these shortcomings ${ }^{9), 13), 20)}$. In addition to land use detection by remote sensing, land use detection may also be conducted with land use data sheets and historical geographical maps using the PLUR program ${ }^{21)}$.

In brief, remote sensing and GIS are considered essential technologies, which enable temporal analysis and qualification of spatial phenomena with less time and low cost.

\section{b) Trends in watershed-based land use modeling}

Watershed-based land use modeling has proved to be a useful tool for land use scenarios studies, as it provides not only the spatial distribution of land use based on the basic spatial data of land use and topography, but also the basic data for calculating landscape pattern metrics and hydrological components. It also provides useful information about the possible environmental impacts of future urbanization $^{22), 23), 24)}$.

In watershed-based land use analysis, six types of land use modeling have frequently been applied. The first model, Conversion of Land Use and Its Effects (CLUE-s), is based on an empirical model measuring the conversion of land use and its effects combined with other models for an integrated approach to simulate and evaluate land use changes, landscape patterns, and their effects on hydrological 
processes at the watershed level ${ }^{22)}$.

The second model, the Land Use Change Modeling Kit (LUCK), is an approach to scenario generation using a grid-based discretization mode at catchment scale. It presents the spatial distribution of land use types in a landscape based on an evaluation of the characteristics of each grid, as well as on its neighborhood relationship. It is used for land use scenario generation providing a spatially distributed specification of land use changes in meso-scale catchments $^{25)}$.

The third model, SLEUTH, is an urban growth model with cellular automation. It is used to estimate present and future surface runoff and peak discharge in small- and medium-sized urban watersheds through land use information derived from satellite images ${ }^{11)}$.

The fourth model, Cellular Automata (CA), is a well-known land use change approach used among peer-reviewed journals. It models urban sprawl by simulating complex dynamic processes through relatively simple rules, and can be applied for urban growth simulation and predicting the extent of an urban area ${ }^{26)}$.

The fifth model, Land Use Transformation (LTM), is applied for forecasting and assessment of the impact of land use changes on runoff, as well as long-term runoff and NPS pollution ${ }^{24), 27), 28), 29)}$.

The sixth model, Markov, is applied for predicting land use structure in the watershed ${ }^{10)}$.

All land use modeling can be categorized based on eight core methodologies: Markov Chains, Economic-Based, Statistical Analysis, Cellular Automata (CA), Geographic-Based, Artificial Neural Network, Agent-Based, and Integration Modeling ${ }^{30)}$. Not all of these methodologies are applicable to watershed-based land use planning. The relationship between the major methodologies and watershedbased land use modeling is shown in Fig. 5.

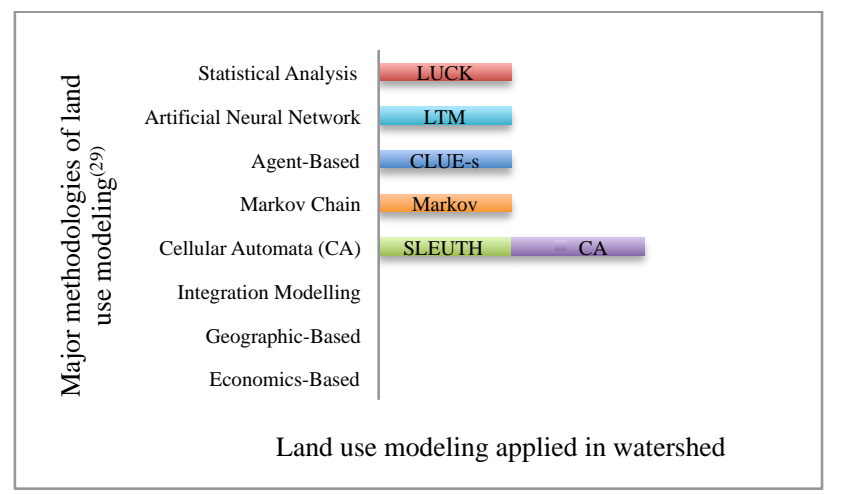

Fig.5 Relationship between the major methodologies of general land use modeling and watershed-based land use modeling.

\section{(2) Trends in threshold definition methods in the watershed delineation process}

Due to advances in desktop GIS capabilities, programming languages, and data availability, many watershed geographical information system (GIS)based applications have been developed since the early 1990s. Hydrological modeling is a welldeveloped technology that has been widely applied with GIS in various studies, in particular those related to geomorphology, soil science, hydrology, and land use planning ${ }^{7)}$. In hydrological modeling, Digital Elevation Models (DEMs) are important and useful sources for automatically generating the flow direction, flow accumulation, stream direction, drainage line, catchment, sub-watershed, and watersheds. This system depends mainly on the input of thresholds in order to identify watersheds.

In brief, the smaller the chosen threshold, the more catchments it produces, which makes the channel complicated. However, the appropriate and reasonable stream threshold for defining the watershed remains unclear, since the only way to determine a reasonable stream threshold is by trial and error, which consumes much time ${ }^{31)}$.

In watershed-based planning, the chosen threshold, which identifies the watershed unit of planning, influences and impacts the planning process. Thus, threshold issues should be discussed clearly in the planning process. Among the 55 target academic papers, two types of watersheds were defined from the planning perspective: rural watersheds and urban watersheds.

\section{a) Rural watersheds}

Rural watersheds refer to original terrain where the natural topography conditions such as landform, surface shape, and the natural drainage pattern and network are not superimposed by infrastructure, such as streets, roads, and buildings. Rural watershed delineation, drainage pattern, and flow calculation have been shown to be capable of being automatically generated through digital terrain models. Of the computer-based terrain representations, grid algorithms such as DEMs were found to be better at defining large rural watersheds than the other two methods, Triangle Irregular Network (TIN) and Contours $^{32)}$. Eight types of applications have been used for watershed-based land use studies. These applications are: GIS-ARC/INFO ${ }^{32), 33), 34), ~ G I S-~}$ GRASS $^{35)}$, TNTmips ${ }^{36), 37)}$ GIS-Hydrological Modeling(6), 38), 39), 40), 41), 42), Terrain Processing in ArcHydro $^{43}$, 44) , and WinGrid system ${ }^{31}$. In addition, certain researchers manually identified the watershed boundary by using topographical maps ${ }^{12)}$, 45). The majority of researchers tended to use the hydrological modeling tool in GIS to delineate the stream network. However, the threshold for defining stream 
network analysis was not discussed widely in the existing literature, though certain researchers were interested in discussing the identified thresholds in rural watersheds ${ }^{31), 38), 39), 40), 41), 43), 46), ~ 47) . ~}$

Five types of existing threshold-defined methods were identified in the target academic papers. The first method was applied using a trial threshold value and used natural topography as the reference for studies carried out to evaluate the green space environment in small watersheds, based on the water cycle ${ }^{40), 41), 46)}$.

The second method involved trialing threshold values for obtaining corresponding average area of watersheds. Threshold was decided on the basis of comparing between the total average areas of administrative boundary with obtained average area of watersheds, for basic studies of land use planning ${ }^{38)}$.

The third method, constant threshold, was defined according to flow accumulation automatically generated by using GIS. This method employed two conditions. The threshold value was set at the lower limit of the generated flow accumulation using hydrological modeling in GIS to identify the potential water flow path ${ }^{39)}$, and the threshold value was set equal to one percent of the upper limit of the generated flow accumulation using Terrain Processing in ArcHydro. This method was used to evaluate the urban spatial characteristics of traditional cities such as a Japanese castle town based on watershed analy$\operatorname{sis}^{43)}$.

In the fourth method, the smallest weighted support area threshold was identified through a defined channel network where the mean stream drop in the first order stream is not statistically different from the mean stream drop in the higher order stream. It was used to define the threshold through an advanced mapping of the flow network from DEMs ${ }^{47)}$.

In the fifth method, the threshold was defined through two modified algorithms: the headwatertracing method and the fitness index ${ }^{31)}$.

From the five aforementioned methods, it can be confirmed that the definition of thresholds is variable and differs between planners.

\section{b) Urban watersheds}

In urban watersheds, the stream network cannot be automatically delineated in its urban terrain since the flow no longer follows its natural path. In urban watersheds the drainage flow path tends to encounter hindrances to flow such as street gutters, which is a result of urban development in the built environment, including buildings, roads, highways, subways, railways, and sewage lines. Basically, the surface drainage system flows through gutters and channels into storm water inlets, which are installed for the purpose of draining the excess runoff from impervious surfaces, namely artificial structures such as paved streets, roofs, sidewalks, and parking lots. The subsurface drainage network of storm sewer pipes, into which the surface water is directed by storm water inlets, is the other drainage network considered in urban watersheds.

For urban watershed planning, the computerbased terrain representation TIN was used with GISARC/INFO to model the storm water flow. It serves as a valuable tool for urban planning and design, especially as it can be used to predict the impact of proposed land use changes and to evaluate land use management strategies. In addition, a tool was developed for further incorporating the GIS spatial analysis into the hydrologic analysis of an urban watershed $^{32)}$. The change of land use in a single lot with a city block corresponding to the nearest storm drain was defined through urban storm watershed modeling $^{33)}$.

These methods can be effective for developing countries, in which the urban flooding associated with surface and subsurface drainage systems is the main urban watershed management issue. Though the applied data are different in scales and resolution, this shortcoming can be minimized through selection of the data sources with minimal scale differences, with the exception of soil maps. However, this method still has some limitations, including digital format availability ${ }^{33)}$. These limitations are even more significant in developing countries, where digital data are less available.

\section{RESEARCH TRENDS IN FACTORS CONSIDERED IN WATERSHED- BASED LAND USE ANALYSIS}

In this section, 36 of the 55 papers are analyzed and categorized according to each factor in their analysis, while the other 19 papers employ mainly basic tools.

Certain papers have two or more purposes defined in a single paper, while some papers have only one purpose associated with the factors. The factors are counted as the basis of all purposes in each target academic paper.

Two main issues are discussed: (1) research trends in factors considered in watershed-based land use analysis, and (2) the relationship of these factors as shown in Table 2.

In this paper, two scales were used in the context of watershed-based land use analysis. 'Local scale' refers to city, regency, district, town, township, ward and village scales, while 'regional scale' refers to province or county scale. These scales depend on the territorial division of each country. 
Table 2 Relationship of factors, characteristics of study region, scale and area in watershed-based land use analysis.

(*) Size of the study area is watershed or catchment area/(**) is drainage area/(***) is watershed area corresponding to administra-

tive area

\begin{tabular}{|c|c|c|c|c|c|c|}
\hline \multirow[b]{2}{*}{ Factors } & \multirow[t]{2}{*}{ Purposes } & \multicolumn{5}{|c|}{ Research trends in factors considered in watershed-based land use analysis } \\
\hline & & Methodologies & $\begin{array}{c}\text { Ref. } \\
\mathrm{N}^{\mathrm{o}}\end{array}$ & \multicolumn{2}{|c|}{$\begin{array}{l}\text { Study region and size } \\
\text { of study area }\left(\mathrm{km}^{2}\right)\end{array}$} & Scale \\
\hline \multirow{5}{*}{ 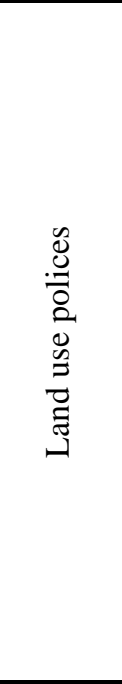 } & \multirow{3}{*}{$\begin{array}{l}\text { Identification of the effec- } \\
\text { tiveness of green space and } \\
\text { local land use policies at a } \\
\text { watershed scale }\end{array}$} & $\begin{array}{l}\text { Quantification of percolation } \\
\text { based on land use policies, } \\
\text { green conservation policy sce- } \\
\text { narios }\end{array}$ & 40) & \multirow{3}{*}{ Asia } & $435^{* * *}$ & City \\
\hline & & $\begin{array}{l}\text { - Quantification of forest and } \\
\text { farmland ratio }\end{array}$ & $\begin{array}{l}6) ; \\
41)\end{array}$ & & $\begin{array}{c}784^{* * *} \\
21^{*}\end{array}$ & $\begin{array}{l}\text { City and } \\
\text { Ward }\end{array}$ \\
\hline & & $\begin{array}{l}\text { - Quantification of percolation } \\
\text { based on first and second } \\
\text { stream order by Horton Strahler }\end{array}$ & 46) & & $41.3^{*}$ & Ward \\
\hline & $\begin{array}{l}\text { Studies of current policies } \\
\text { on watershed conservation }\end{array}$ & $\begin{array}{l}\text { - Based on land use policies } \\
\text { documents and interviewing }\end{array}$ & $\begin{array}{l}3) ; \\
42)\end{array}$ & $\begin{array}{l}\text { North } \\
\text { America } \\
\text { and Oce- } \\
\text { ania }\end{array}$ & $\begin{array}{l}2776^{* *} \\
365^{* * *}\end{array}$ & Regional \\
\hline & $\begin{array}{l}\text { Analysis of the influence of } \\
\text { land use policies on land } \\
\text { use structure }\end{array}$ & $\begin{array}{l}\text { - Considering slope degree as } \\
\text { the most important factor }\end{array}$ & 48) & Asia & $3.9^{*}$ & Village \\
\hline \multirow{5}{*}{ 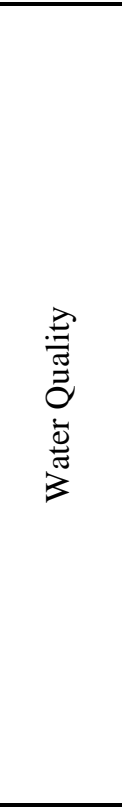 } & \multirow{4}{*}{$\begin{array}{l}\text { Exploring the relationships } \\
\text { between water quality and } \\
\text { land use }\end{array}$} & $\begin{array}{l}\text { - Biology, water chemistry and } \\
\text { habitat were used to demon- } \\
\text { strate the relationship between } \\
\text { the quality of the receiving river } \\
\text { and land use }\end{array}$ & 51) & \multirow{3}{*}{$\begin{array}{l}\text { North } \\
\text { America }\end{array}$} & $4550^{* *}$ & \multirow{3}{*}{ Regional } \\
\hline & & $\begin{array}{l}\text { - Electrolytic conductivity as } \\
\text { indicator }\end{array}$ & 34) & & $9700^{* * *}$ & \\
\hline & & $\begin{array}{l}\text { - The parameters of the water } \\
\text { quality such as total nitrogen } \\
\text { (TN), total phosphorus (TP), } \\
\text { chemical oxygen demand } \\
\text { (COD), and biochemical oxy- } \\
\text { gen demand (BOD) }\end{array}$ & 10) & & $2840.7^{* *}$ & \\
\hline & & $\begin{array}{l}\text { - Water Quality Index as indi- } \\
\text { cator }\end{array}$ & 12) & Asia & $50^{*}$ & District \\
\hline & $\begin{array}{l}\text { Assessment of the impact } \\
\text { of land use and land cover } \\
\text { changes (LUCCs) on the } \\
\text { surface water quality }\end{array}$ & $\begin{array}{l}\text { - Water quality parameters } \\
\text { (WQPs) such as pH, TAN, } \\
\text { BOD5, FCs, TCs, EC, } \mathrm{NO}^{-3} \text {, } \\
\text { and } \mathrm{NO}^{-2} \text { as indicators }\end{array}$ & 52) & Europe & $5063.9^{*}$ & Regional \\
\hline \multirow{5}{*}{ 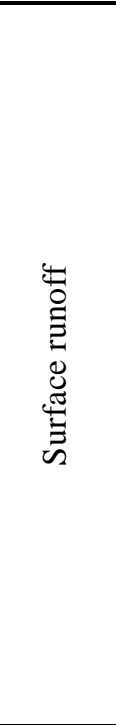 } & \multirow{5}{*}{$\begin{array}{l}\text { Identifying, estimating, } \\
\text { analyzing, quantifying, and } \\
\text { simulating the impact of } \\
\text { land use change }\end{array}$} & $\begin{array}{l}\text { - Estimation of the increase of } \\
\text { annual average runoff from wa- } \\
\text { tershed using the L-THIA mod- } \\
\text { el }\end{array}$ & 2) & \multirow{3}{*}{$\begin{array}{l}\text { North } \\
\text { America }\end{array}$} & $70.5^{*}$ & \multirow{3}{*}{ Regional } \\
\hline & & $\begin{array}{l}\text { - Estimation of surface runoff } \\
\text { using the combination between } \\
\text { the LTM and L-THIA model }\end{array}$ & 27) & & $7032^{*}$ & \\
\hline & & $\begin{array}{l}\text { - Surface runoff simulation de- } \\
\text { fined through the combination } \\
\text { of the SCS model and storm } \\
\text { water management model }\end{array}$ & 29) & & $\begin{array}{l}1963^{*}- \\
4007^{*}\end{array}$ & \\
\hline & & $\begin{array}{l}\text { - Qualification of the impact of } \\
\text { land use change on surface run- } \\
\text { off with the aid of the SWAT } \\
\text { hydrological model }\end{array}$ & $\begin{array}{l}23) ; \\
53)\end{array}$ & $\begin{array}{l}\text { North } \\
\text { America } \\
\text { and } \mathrm{Eu-} \\
\text { rope }\end{array}$ & $\begin{array}{c}0.26^{*}- \\
82^{*} ; 316^{*}\end{array}$ & $\begin{array}{l}\text { Regional } \\
\text { and Dis- } \\
\text { trict }\end{array}$ \\
\hline & & $\begin{array}{l}\text { - Calculating surface runoff } \\
\text { from satellite image information }\end{array}$ & 11) & $\begin{array}{l}\text { North } \\
\text { America }\end{array}$ & $373^{*}$ & Town \\
\hline
\end{tabular}




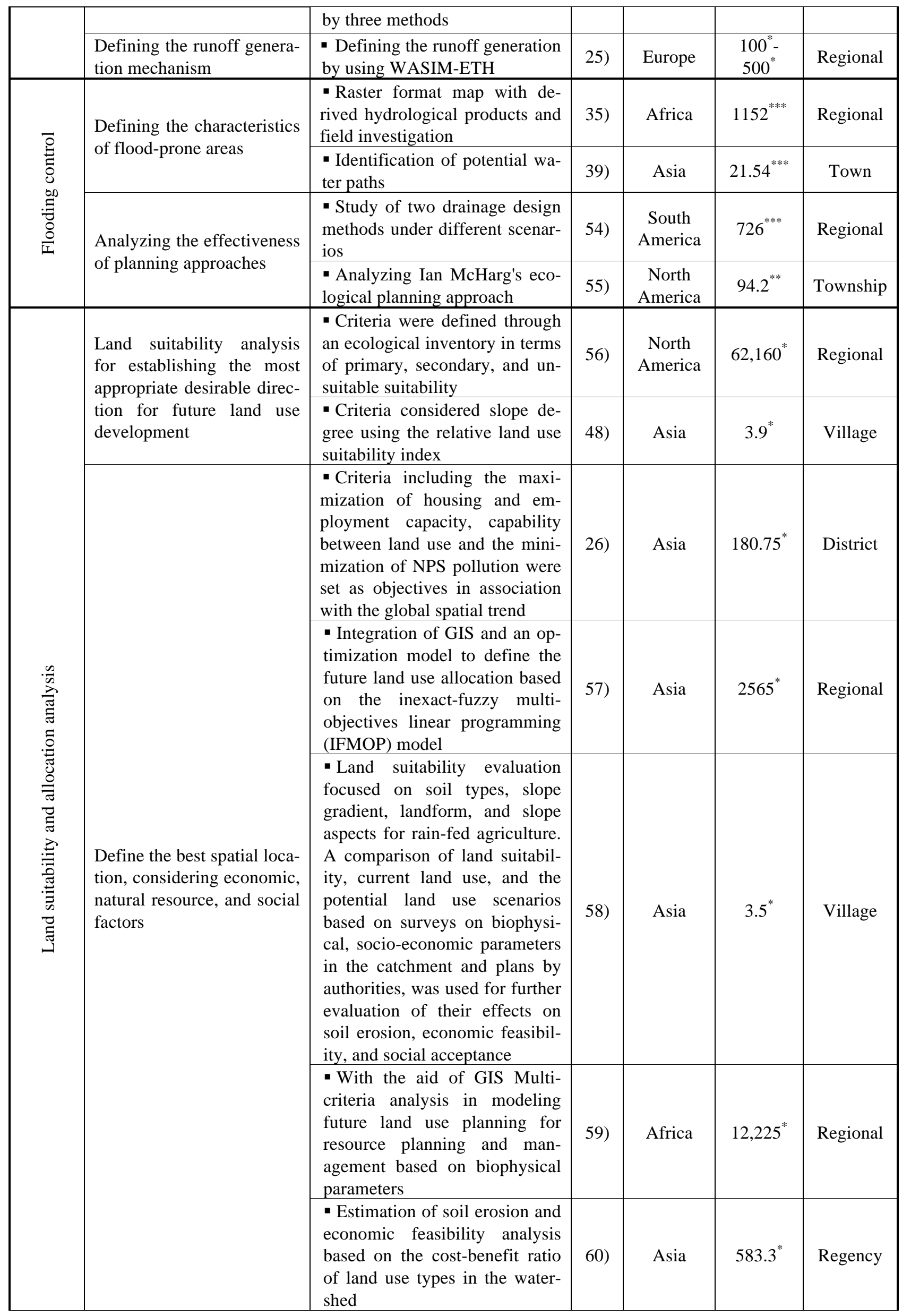




\begin{tabular}{|c|c|c|c|c|c|c|}
\hline & \multirow[b]{2}{*}{$\begin{array}{l}\text { Identification of site priori- } \\
\text { tization }\end{array}$} & $\begin{array}{l}\text { - Identification of site prioriti- } \\
\text { zation for low-impact develop- } \\
\text { ment (LID) }\end{array}$ & 61) & $\begin{array}{l}\text { North } \\
\text { America }\end{array}$ & $666^{*}$ & Regional \\
\hline & & $\begin{array}{l}\text { - Defining the potential sites } \\
\text { for the placement of the con- } \\
\text { servation buffer and riparian } \\
\text { restoration in the watershed }\end{array}$ & 62) & $\begin{array}{l}\text { North } \\
\text { America }\end{array}$ & $80.29^{*}$ & Township \\
\hline \multirow{4}{*}{ 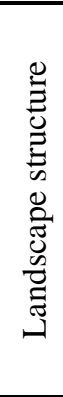 } & \multirow{4}{*}{$\begin{array}{l}\text { Clarifying landscape struc- } \\
\text { ture and its relationship } \\
\text { with land use }\end{array}$} & $\begin{array}{l}\text { - Using landscape indices such } \\
\text { as patch number per unit area, } \\
\text { mean patch area of different }\end{array}$ & $\begin{array}{l}12) ; \\
45) ; \\
63)\end{array}$ & \multirow{3}{*}{ Asia } & $\begin{array}{l}50^{*} ; \\
50.97^{*} \\
153.35^{*}\end{array}$ & District \\
\hline & & \multirow{2}{*}{$\begin{array}{l}\text { land use types, diversity index } \\
\text { (H) }\end{array}$} & 48) & & $3.9^{*}$ & Village \\
\hline & & & 16) & & $190^{*}$ & Regional \\
\hline & & $\begin{array}{l}\text { - Using the characteristics of } \\
\text { the natural environment such as } \\
\text { topography, slope, and vegeta- } \\
\text { tion conditions }\end{array}$ & $\begin{array}{l}37) ; \\
42)\end{array}$ & $\begin{array}{l}\text { Asia and } \\
\text { Oceania }\end{array}$ & $\begin{array}{l}1043^{*}- \\
3720^{*} ; \\
365^{* * * *}\end{array}$ & Regional \\
\hline
\end{tabular}

(1) Trends in factors considered in watershedbased land use analysis

The research trends in watershed-based land use analysis were analyzed and categorized into six factors: land use policies, water quality, surface runoff, flooding control, land suitability and allocation analysis, and landscape structure.

\section{a) Land use policies}

Many methods contribute to the study of watershed-based land use analysis in terms of land use policies. Three main methods focusing on the influences, impacts, and consequences of land use practices on watershed-based land use policies were identified.

First, in order to identify the effectiveness of green space and local land use policies at a watershed scale, the quantity of percolation was quantified based on the land use policy and greenery conservation policy scenarios. The effectiveness of the current conservation of green space was revealed ${ }^{40)}$. Quantifying the forest and farmland ratio was also used for environmental conservation and disaster prevention. The effectiveness of using the watershed as a planning unit to reflect finer level planning in terms of natural conditions and social background was defined ${ }^{6}$, and the environment of small watersheds was evaluated ${ }^{41)}$. Percolation, with the index of the water cycle focusing on the first and second stream order by Horton-Strahler, was quantified. Transformation of the green space environment on both scales made it possible to consider the restoration of the policy ${ }^{46}$.

Second, in studies of current policies on watershed conservation, studies of land use policy documents were conducted, and policy-makers were interviewed. Negligible numbers of land use planning measures for protecting forest and open space through the watershed were found ${ }^{3)}$. In addition, state officers and local community organizations were interviewed, and delivers urgent issues were carried out ${ }^{42}$.

Third, the influence of land use policies on land use structure was analyzed using slope degree as the defining factor. The new land use system was found to be better than the previous one ${ }^{48)}$.

\section{b) Water quality}

Generally, the study of stream quality and function depends on five variables: climate, geology, soil, land use, and vegetation. Land use is considered to have direct control of and impact on watershed health ${ }^{49), 50)}$. These impacts are dominated by contaminants released into the natural environment, which are normally classed as point source and nonpoint source pollution. Water pollution affects two separate resources: surface water and groundwater. However, in the study of watershed-based land use analysis, surface water pollution is the primary focus among researchers. This pollution is mainly due to the gradual progression of the urbanization process, in terms of discharge from wastewater treatment plants (WWTP), excess fertilizers from agricultural lands, causing a number of ecological effects and adverse health due to an overabundance of nutrients including nitrogen and phosphorus in the water, residential areas, and toxic chemicals from urban runoff.

Many researchers have studied and discussed water quality as one of the factors considered in watershed-based land use analysis. This research can be classified as having two main purposes, each with different corresponding methodologies.

The first purpose is to explore the relationship between water quality and land use. In this context, biology, water chemistry, and habitat were used to demonstrate the relationship between the quality of the receiving river and land use, which showed that increasing population pressures have resulted in increasing loads of nutrients and other pollutants in 
the watershed ${ }^{51)}$. Electrolytic conductivity, a general indicator for water quality, is more appropriately used to diagnose the impacts from point pollution sources rather than non-point pollution sources, in order to define the relationship between water quality and land use ${ }^{34)}$. Parameters measuring water quality such as total nitrogen (TN), total phosphorus (TP), chemical oxygen demand (COD), and biochemical oxygen demand (BOD) revealed that change in land use types have led to a tendency towards moderate decline in water quality ${ }^{10)}$. The water quality index (WQI) demonstrates that with proper land use planning, water quality can be protected and economic goals can be achieved ${ }^{12)}$.

The second purpose is to make an assessment of the impact of land use and land cover changes (LUCCs) on the surface water quality. Water quality parameters (WQPs) such as $\mathrm{pH}$, total ammoniacal nitrogen (TAN), 5-day biochemical oxygen demand (BOD5), fecal coliforms (FCs), total coliforms (TCs), electric conductivity in field $\left(20^{\circ} \mathrm{C}\right)(\mathrm{EC})$, total nitrate $\left(\mathrm{NO}^{-3}\right)$, and total nitrite $\left(\mathrm{NO}^{-2}\right)$ were used as indicators. These showed that higher water quality protection can be achieved with greater forest occupation in water reservoirs ${ }^{52)}$.

\section{c) Surface runoff}

In general terms, surface runoff is defined as the flow of water occurring when excess storm water is generated during precipitation and snowmelt. It can infiltrate, evaporate, and its runoff can end up in nearby water bodies such as streams, rivers, lakes, and other surface water sources. Moreover, it occurs when there is heavy rain whose flow amount is beyond the absorption capacity of the soil. The increase in the size and number of impervious areas, which is a direct result of land use change and urban development, increases surface runoff. Surface runoff can cause not only water erosion and pollution, but is also the primary cause of urban flooding.

Being aware of and responding to those negative outcomes, many studies have carried out watershedbased land use analysis using surface runoff as a factor. Two main purposes and their corresponding methods were identified in this category of the target academic papers. Surface runoff was used as an indicator in 7 of the 36 target academic papers.

The first purpose is identifying, estimating, analyzing, quantifying, and simulating the impact of land use change on surface runoff. In this context, a long-term hydrological impact assessment, the LTHIA model, was developed for estimating the increase in annual average runoff from the watershed due to land use change. Owing to the intensified pressure on the natural environment due to the increase in impervious areas in the urban environment, the traditional short-term local-scale surface hydrological models focusing on estimating peak discharges and high-magnitude NPS pollution are not sufficient. An increase in annual average runoff volume and metals but decrease in nitrogen and phosphorus load were estimated in terms of increasing urbanization ${ }^{2)}$. Estimation of surface runoff for land use in different periods was defined using a combination of the LTM and L-THIA models. Essential information about future urbanization and the possibility of environmental impacts can be generated; this could be a potential research direction for the future ${ }^{27}$. Simulation of surface runoff before and after urbanization was defined using a combination of the soil conservation service (SCS) and the storm water management models. A risk of increased flood discharge and decreased quality of aquatic systems was identified ${ }^{29)}$. Surface runoff from satellite image information was also calculated using three methods existing in numerous literatures, namely the SCS, Arthur's, and Peak surface runoff models. Increased inefficiency in the use of land was also identified as a factor that increases surface runoff $^{11)}$. Moreover, quantification of the impact of land use changes on surface runoff can be conducted with the aid of the SWAT hydrological model, a river basin scale model developed to estimate the impact of land management practices in large and complex watersheds with varying soil types, land use, and management purposes over a long period of time. Surface runoff was identified as the factor most susceptible to land use change in both artificial and natural catchments ${ }^{23}$. Decreased forest cover led to an increase in surface runoff in the studied watershed ${ }^{53)}$.

The second purpose is to define the runoff generation mechanisms, including infiltration excess overland flow, saturation excess, subsurface storm flow, and quick groundwater outflow, which are likely to be affected by land use change and its influence on storm runoff generation. This study used an extension of the hydrological model, WASIMETH, including most of the processes relevant to runoff generation, by considering the spatial distribution of catchment characteristics and spatial temporal dynamics of climate variables, and improving the representation of the influence of land cover and the unsaturation zone on the infiltration process. High dependency on rainfall event characteristics and their spatial scale were identified ${ }^{25)}$.

\section{d) Flooding control}

Flood control is becoming one of the major questions in urban planning as well as land use planning. The urbanization process lowers the infiltration rate by substituting impervious cover for natural vegetation, and increases in discharge rate are the direct result of high water velocity. These lead to increased 
vulnerability to urban flooding; moreover, these problems are even worse for developing countries since industrialization has concentrated the urbanization process in the past half century ${ }^{54)}$. Considering these problems, flood control as a factor in watershed-based planning and land use analysis was categorized with two main purposes.

The first purpose is to define the characteristics of flood prone areas. These were defined through raster format maps with derived hydrological products and field investigation. Flood-prone areas were identified $^{35)}$. From the viewpoint of geography and urban disaster prevention, flood-prone areas can be used as hazard maps defined through the identification of potential water paths ${ }^{39)}$.

The second purpose is to define the effectiveness of planning approaches. Two drainage system design methods were analyzed: traditional channelization intervention or end of pipe solutions, and the distributed storm water management approach, based on sustainable urban drainage systems (SUDS). The objectives of this is to minimize the quality and quantity problems related to urban development's effect on the natural environment, and maximize amenities and biodiversity opportunities under different scenarios, considering distinct future urban development possibilities. The traditional approach distributes floods downstream at any time, while the distributed measures over the basin showed a high possibility of adaptation to the future urban pattern ${ }^{54)}$. Ian McHarg's ecological planning approach based on hydrological properties related with land use change, storm water, runoff and discharge was evaluated for its effectiveness for flooding control, and the best solution among the development approaches compared in the study was identified $^{55)}$.

\section{e) Land suitability and allocation analysis}

Among the target academic papers, two types of analysis were identified considering the influence and impact of land use practices on the natural environment and their related consequences on a watershed scale.

The first type is land suitability analysis, an approach establishing the most appropriate desirable direction for future land use development. In order to identify the most appropriate site, the suitability of various land uses for exploring the growth direction was identified. Criteria for four different types of land use, namely low-density housing, commercial development, industrial development, and recreation were defined using an ecological inventory of the Gila river watershed in terms of primary suitability, secondary suitability and unsuitability for certain land uses. This method can be applied to other rural areas of the American West ${ }^{56}$. Slope de- gree was considered to be the main factor in the suitability analysis, in particular, for the area dominated by soil erosion by using the relative land use suitability index (R), which was then used to define the suitability of the land use structure. It was clarified that the current land use structure was suitable $^{48)}$.

The second type is land allocation analysis, which is conducted to integrate land use planning with effective environmental management, considering economic and social conditions. Land allocation analysis has two general objectives.

The first objective is to define the best spatial location taking consideration of economic, natural resource and social factors. In this sense, the land use optimization plan was defined, focusing on four criteria: the maximization of housing, employment capacity, compatibility between land uses, and the minimization of NPS pollution. It was demonstrated that these models were appropriate for use in areas undergoing urban expansion ${ }^{26)}$. Integration of GIS and the optimization model was used to define the future land use allocation based on the inexact-fuzzy multi-objectives linear programming (IFMOP) model, allowing uncertainties including decisions, objectives, and constraints to be communicated in the program and generate solutions. However, this method is for real-time planning; environmental and socio-economic conditions change ${ }^{57)}$. An approach to sustainable land use planning satisfying natural eco-environmental conditions, economic conditions, and local farmers' acceptance and participation, was conducted, where the land suitability evaluation focused on soil types, slope gradient, landform, and slope aspects for rain-fed agriculture. A comparison of land suitability, current land use, and potential land use scenarios based on surveys of biophysical and socio-economic parameters in the catchment and plans by authorities, was used for further evaluation of the effects on soil erosion, economic feasibility and social acceptance. A good choice of land use scenarios with respect to ecological/biological factors was defined ${ }^{58)}$. The best allocation of land for future agriculture and forest development was identified with the aid of GIS multi-criteria analysis in modeling future land use for resource planning and management based on biophysical parameters ${ }^{59)}$. A realistic soil conservation plan and its implementation in Indonesia was analyzed by conducting an estimation of soil erosion and economic feasibility analysis based on the cost-benefit ratio of land use types in the watershed. It was demonstrated that land use to optimize economic profit/benefit was the preferred option ${ }^{60)}$.

The second objective is site prioritization. In this context, the site prioritization was conducted for 
low-impact development (LID), a land use planning method used to improve water quality in the urban watershed and mitigate urban impacts to the environment at the sub-catchment level. Hydrological sensitive areas (HSAs) were identified using a multi-variable topographic index and calculation of suitability for LID application in terms of land use, spatial scale, position in the stream network and the effectiveness of impervious areas. This method enables the mitigation of the effects of urban land use and allows cost-effective land use planning decisions to be made regarding stream ecosystems across diverse landscapes ${ }^{61)}$. Potential sites were identified for the placement of the conservation buffer and riparian restoration in the watershed, in which the delineation of the exact extent and boundary of the riparian landscape was often difficult, remaining an issue of debate. A power-screening tool for defining potential sites for conservation buffers and riparian restoration placement in watersheds was defined ${ }^{62)}$.

\section{f) Landscape structure}

Landscape structure is defined as the result of the complex interaction between physical, biological, political, economic, and social driving forces; change in landscape structure causes change in its function.

In recognition of the complex interactions involved, watershed-based land use analysis with landscape structure as an indicator primarily focused on clarifying landscape structure and its relationship with land use through two methods.

The first method is to use landscape indices. In this method, landscape indices such as patch number per unit area, mean patch area of different land use types, and diversity index (H), are used for describing information change and landscape pattern analysis. Fractal dimensions for measuring patch shape complexity, the evenness index derived from the Shannon Evenness Index, and the landscape fragmentation index, were analyzed with related land use types. The reliability of using these indices for measuring and evaluating land use/land cover change was illustrated ${ }^{12}$. The impact of urbanization on landscape characteristics and their consequences were elucidated in an urban lake watershed ${ }^{16)}$. In addition, landscape structure and land use change can be identified with a fixed 50-m width buffer zone for all stream orders, in which the stream networks were derived from Strahler's stream ordering system $^{45)}$. Moreover, the land use and landscape structure were also identified through patchiness and degree of irregularity of different land use plots focusing on a shape complexity index (SCI) for investigating the change in forest patch complexity at the polygon level. This technique works by comparing the SCI of existing forest polygons with the optimum SCI polygon shape. Essential information of change occurred in forest areas and other major land uses in the studied watershed were identified ${ }^{63)}$. The relationship between land use and landscape factors was defined using landscape indices such as area, areal percentages, and patch number per land use type. Fragmentation in the study area after land reform was shown ${ }^{48)}$.

The second method is to use the characteristics of the natural environment such as topography, slope, and vegetation conditions to clarify the relationship between land use and landscape structure. Types of land use changes and main components in terms of topography, land use, and soil were determined ${ }^{37}$; Landscape structure, function, and change were clarified $^{42)}$.

\section{FINDINGS}

In reviewing watershed-based land use analysis, the research trends of basic tools, factors, methodologies, characteristics of study regions, scales, and areas were examined in 55 target academic papers. On the basis of the findings, some conclusions can be made:

First, in recognition of the land use detection method trends, several sources of information including current satellite data and corresponding software were demonstrated to be in use. Furthermore, for high-precision land use detection, the integration of remote sensing (RS) and GIS was proven to be an important technology for temporal analysis and qualification of spatial phenomena, particularly as it allowed for land use analysis with less time and low cost. However, higher spatial resolution satellite data are needed for detecting land use change in detail. Moreover, it has proved to be a useful tool to apply to watershed-based land use analysis with the major methodologies of land use modeling.

Second, terrain analysis based on the digital elevation model has been used widely not only in the fields of hydrology, water resource planning, and other fields, but also in city and regional planning. As the study of the watershed as a planning unit has moved into a new age with the aid of geographical information systems, the definition, application, and the use of a variety of indicators, particularly in rural watersheds, will become even more critical. From the viewpoint of watershed scale planning, the nature of using an application to analyze watersheds is not static. There is much variation among planners because the threshold values, used for stream definition differ. Therefore, close attention should be paid to the process of watershed analysis. With 
these concerns as a basis, it is proposed that instead of using constant thresholds, more appropriate and standard methods should be defined in order to bridge the gap between the actual watershed and the watershed delineated in the application. On the other hand, in urban watersheds, where the output information of the modeling is necessary to solve the problem of urban flooding, it is essential for future research to give more attention to the methods, in particular, for the majority of developing countries, where data are lacking and urban flooding is the main issue.

Third, studies have shown that the research trends in factors considered in watershed-based land use analysis and the relationships between these factors, characteristics of study areas, scales, and areas are generally discussed at both the regional and the local scale.

ACKNOWLEDGMENTS: We express our deepest gratitude to the Ministry of Education, Culture, Sports, Science and Technology, Government of Japan for the funding that supported the research for this paper.

\section{REFERENCES}

1) DeFries, R. and Eshleman, K. N. : Land-use change and hydrologic processes: A major focus for the future, Hydro. Process, Vol. 18, pp. 2183-2186, 2004.

2) Bhaduri, B., Harbor, J. O. N., Engel, B. and Grove, M. : Assessing watershed-scale, long-term hydrologic impacts of land-use change using a GIS-NPS model, Environmental Management, Vol. 26, No. 6, pp. 643-658, 2000.

3) Erickson, D. L. : Rural land use and land cover change, Land Use Policy, Vol. 12, No. 3, pp. 223-236, 1995.

4) Kauffman, G. J. : What if the United States of America were based on watersheds?, Water Policy, Vol. 4, pp. 5768, 2002.

5) National Research Council (U.S.): Committee to Review the New York City Watershed Management Strategy : Watershed management for potable water supply: Assessing the New York City Strategy, National Academy Press, pp. 45-87, 2000

6) Katagiri, Y. and Ishikawa, M. : A study on landscape planning based on watershed unit in Sendai metropolitan area, J. Japanese Institute of Landscape Architecture, Vol. 75, No. 5, pp. 673-676, 2012.

7) Strager, M. P., Fletcher, J. J., Strager, J. M., Yuill, C. B., Eli, R. N., Petty, J. T. and Lamont, S. J. : Watershed analysis with GIS: The watershed characterization and modeling system software application, Computer \& Geosciences, Vol. 36, Issue 7, pp. 970-976, 2010.

8) Anderson, J. R., Hardy, E. E., Roach, J. T. and Witmer, R. E. : A land use and land cover classification system for use with remote sensor data, U.S. Geological Survey Professional Paper, No. 964, USGS, Washington, D.C. 1976.

9) Rawal, H. S., Rawat, J. S., Kumar, M., Pant, N. C. and Rani, N. : Land use/ cover dynamics of Kail watershed, central Himalaya, India using remote sensing and GIS technique, Int. J. Advancement in Remote Sensing, GIS and Geography, Vol. 2, No.2, pp. 55-59, 2014.

10) Hong, Z., Hailin, L. and Zhen, C. : Analysis of land use dynamic change and its impact on the water environment in Yunnan Plateau lake area- A case study of the Dianchi Lake drainage area, Procedia Environmental Sciences, Vol. 10, pp. 2709-2717, 2011.

11) Carlson, T. N. : Analysis and prediction of surface runoff in an urbanizing watershed using satellite imagery, $J$. American Water Resources Association, Vol. 40, Issue 4, pp. 1087-1098, 2004.

12) Yunus, A. J. M., Nakagoshi, N. and Ibrahim, A. L. : Application of GIS and remote sensing for measuring and evaluating land use change and its impact on water quality in the Pinang River Watershed, Ecol. Civil. Eng., Vol. 6, No. 1, pp. 97-110, 2003.

13) Butt, A., Shabbir, R., Ahmad, S. S. and Aziz, N. : Land use change mapping and analysis using remote sensing and GIS: A case study of Simly watershed, Islamabad, Pakistan, The Egyptian Journal of Remote Sensing and Space Sciences, Vol. 18, Issue 2, pp. 251-259, 2015.

14) Ghimire, S. K. and Higaki, D. : Study of recent changes in land use and stream course with reference to geomorphologic characteristics in the Siwalik Hills of Nepal, J. the Japan Society of Erosion Control Engineering, Vol. 57, No. 5, pp. 25-31, 2005.

15) Wen, Y., Khosrowpanah, S. and Heitz, L. : Land cover change of watersheds in Southern Guam from 1973 to 2001, Environ. Monit. Assess., Vol. 179, pp. 521-529, 2011.

16) Li, Y., Zhao, S., Zhao, K., Xie, P. and Fang, J. : Landcover changes in an urban lake watershed in a mega-city, central China, Environ. Monit. Assess., Vol.115, pp. 349359, 2006.

17) Senevirathne, N., Mony, K., Samarakoon, L. and Hazaraki, M. K. : Land use/land cover change detection of Tonle Sap Watershed, Cambodia, $31^{\text {st }}$ Asian Conference on Remote Sensing (ACRS), Vol. 1, pp. 852-857, 2010.

18) Apan, A. A., Raine, S. R. and Paterson, M. S. : Mapping and analysis of changes in the riparian landscape structure of the Lockyer Valley catchment, Queensland, Australia, Landscape and Urban Planning, Vol. 59, Issue 1, pp, 4357, 2002.

19) Lu, D. and Weng, Q. : A survey of image classification methods and techniques for improving classification performance, International Journal of Remote Sensing, Vol. 28, No. 5, pp. 823-870, 2007.

20) Kunihiko, Y., Yudi, S. and Eikichi, S. : Land use analysis using time series of vegetation index derived from satellite remote sensing in Brantas River watershed, East Java, Indonesia, The International Symposium on Cartography in Internet and Ubiquitous Environments, 2015.

21) Luo, P., Takara, K., Apip, He, B., Nover, D. and Yamashi$\mathrm{ki}, \mathrm{Y}$. : Land use change analysis and paleo-flood in the Kamo River basin, Kyoto, Japan, J. Hydrologic Engineering, Vol. 68, No. 4, pp. 127-132, 2012.

22) Lin, Y. P., Hong, N. M., Wu, P. J., Wu, C. F. and Verburg, P. H. : Impacts of land use change scenarios on hydrology and land use patterns in the Wu-Tu watershed in Northern Taiwan, Landscape and Urban Planning, Vol. 80, pp. 111126, 2007.

23) Fohrer, N., Haverkamp, S., Eckhardt, K. and Frede, H. G. : Hydrologic response to land use changes on the catchment scale, Phys. Chem. Earth (B), Vol. 26, No. 7-8, pp. 577582, 2001.

24) Takamatsu, M., Kawasaki, A., Rogers, P. P. and Malakie, J. L. : Development of a land-use forecast tool for future water resources assessment: Case study for the Mekong River 3S Sub-basins, Sustain Sci., Vol. 9, pp. 157-172, 2014.

25) Niehoff, D., Fritsch, U. and Bronstert, A. : Land-use impacts on storm-runoff generation: Scenarios of land-use change and simulation of hydrological response in a meso- 
scale catchment in SW-Germany, J. Hydrology, Vol. 267, pp. 80-93, 2002.

26) Huang, B. and Zhang, W. : Sustainable Land-use planning for a downtown lake area in central China: Multi-objective optimization approach aided by urban growth modeling, $J$. Urban Planning and Development, Vol. 140, Issue 2, 2014

27) Tang, Z., Engel, B. A., Pijanowski, B. C. and Lim, K. J. : Forecasting land use change and its environmental impact at a watershed scale, J. Environmental Management, Vol. 76, pp. 35-45, 2005.

28) Pijanowski, B. C., Shellito, B., Pithadia, S. and Alexandridis, K. : Forecasting and assessing the impact of urban sprawl in coastal watersheds along eastern Lake Michigan, J. Lakes \& Reservoirs: Research and Management, Vol. 7, 2002.

29) Yan, H. and Edwards, F. G. : Effects of land use change on hydrologic response at a watershed scale, Arkansas, J. Hydrologic Engineering, Vol. 18, pp. 1779-1785, 2013.

30) Nguyet, D. A. and Kawasaki, A. : Review of current approaches and new trends in land-use change projection modeling, Seisan Kenkyu, Vol. 65, No. 4, pp. 509-515, 2013.

31) Lin, W. T., Chou, W. C., Lin, C. Y., Huang, P. H. and Tsai, J. S. : Automated suitable drainage network extraction from digital elevation models in Taiwan's upstream watersheds, Hydro. Process, Vol. 20, Issue 2, pp. 289-306, 2006.

32) Djokic, D. and Maidment, D. R. : Terrain analysis for urban stormwater modeling, Hydro. Process, Vol. 5, pp. 115124, 1991.

33) Greene, R. G. and Cruise, J. F. : Urban watershed modeling using Geographic Information System, J. Water Resources Planning and Management, Vol. 121, Issues 4, pp. 318-325, 1995.

34) Wang, X. and Yin, Z. Y. : Using GIS to assess the relationship between land use and water quality at a watershed level, Environment International, Vol. 23, No.1, pp. 103114, 1997.

35) Masoud, A. A., Raghavan, V., Masumoto, S. and Shiono, K. : Stream network and basin boundary extraction using GRASS GIS: EL-Barud Basin, Safaga Area, Red Sea Coast, Egypt, Geoinformatics, Vol. 13, No. 4, pp. 205-212, 2002.

36) Ohbi, K. and Suzuki, M. : A study on the watershed classification using grid cell data, J. The Japanese Institute of Landscape Architecture, Vol. 66, No. 5, pp. 871-876, 2002

37) Ohbi, K. and Suzuki, M. : An analysis of land-use transition based on watershed units using the national digital information data base, J. The Japanese Institute of Landscape Architecture, Vol. 65, No. 5, pp. 861-864, 2001.

38) Minami, J., Usui, N., Shimizu, H., Murayama, A. and Otsuki, A. : A Basic Study on land use planning focused on watershed: Case of Ise Bay basins area, J. Architectural Institute of Japan, Vol. 45, pp. 601-604, 2007.

39) Inoue, K., Shimizu, H. and Otsuki, A. and Murayama, A. : Development of a method to visualize a "Water Path Network" in an urban area using GIS, J. Archit. Plann., AIJ, Vol. 74, No. 635, pp. 107-112, 2009.

40) Katagiri, Y., Yamashita, H. and Ishikawa, M. : An evaluation method for the plan of greenery and open space based on small watershed unit, J. The Japanese Institute of Landscape Architecture, Vol. 70, No. 5, 2007.

41) Katagiri, Y., Yamashita, H. and Ishikawa, M. : A study on the database of the watershed unit based on the common data, and the analysis and evaluation method for the open space planning, J. The Japanese Institute of Landscape Architecture, Vol. 67, No. 5, 2004.

42) Iida, A. : A study on watershed-based landscape planning on Babeldaob Island in the Republic of Palau, Environ- mental Design Research, Vol. 1, 2012.

43) Lim, L. and Sasaki, Y. : Methodology to evaluate the urban spatial characteristics of traditional cities by watershedbased analysis, The 15th Science Council of Asia Conference and International Symposium, pp. 38-44, 2015.

44) Kawasaki, A., Takamatsu, M., He, J., Rogers, P. and Herath, S. : An integrated approach to evaluate potential impact of precipitation and land-use change on streamflow on Srepok River basin, Theory and Applications of GIS, Vol. 18, No.2, pp. 9-20, 2010.

45) Yunus, A. J. M., Nakagoshi, N. and Ibrahim, A. L. : Riparian land-use and land cover change analysis using GIS in Pinang river watershed, Malaysia, Tropics, Vol. 13, No. 4, pp. 235-248, 2004.

46) Katagiri, Y., Yamashita, H. and Ishikawa, M. : A study on the transition of open space in small watershed from the viewpoint of water cycle, $J$. The Japanese Institute of Landscape Architecture, Vol. 68, No. 5, Landscape Research Japan, pp. 913-918, 2004.

47) Tarboton, D. G. and Ames, D. P. : Advances in the mapping of flow networks from digital elevation data, World Water and Environmental Resources Congress, 2001.

48) Chen, L., Wang, J., Fu, B. and Qiu, Y. : Land use change in a small catchment of northern Loess Plateau, China, $A g$ riculture, Ecosystems and Environment, Vol. 86, pp. 163$172,2001$.

49) Morisawa, M. and LaFlure, E. : Hydraulic geometry, stream equilibrium and urbanization, Proceedings of the 10th Annual Geomorphology Symposium Series, D. D. Rhodes and G. P. Williams (eds.), Binghamton, NY, 1979.

50) Brabec, E., Schulte, S. and Richards, P. L. : Impervious surfaces and water quality: A review of current literature and its implications for watershed planning, J. Planning and Literature, Vol. 16, No. 4, pp. 499-514, 2002.

51) Wang, $X$. : Integrating water-quality management and land-use planning in a watershed context, J. Environmental Management, Vol. 61, pp. 25-36, 2001.

52) Meneses, B. M., Reis, R., Vale, M. J. and Saraiva, R. : Land use and land cover changes in in Zêzere watershed (Portugal) - Water quality implications, Science of the Total Environment, Vol. 527-528, pp. 439-447, 2015.

53) Coutu, G. W. and Vega, C. : Impacts of land use changes on runoff generation in the east branch of the Brandywine Creek watershed using a GIS-Based hydrological model, Middle States Geographer, Vol. 40, pp. 142-149, 2007.

54) Miguez, M. G., Rezende, O. M. and Veról, A. P. : City growth and urban drainage alternatives: sustainability challenge, J. Urban Planning and Development, Vol. 141, Issue 3, 2015.

55) Yang, B. and Li, M. H. : Assessing planning approaches by watershed streamflow modeling: Case study of the Woodland, Texas, Landscape and Urban Planning, Vol. 99, pp. 9-22, 2011.

56) Steiner, F., McSherry, L. and Cohen, J. : Land suitability analysis for the upper Gila River watershed, Landscape and Urban Planning, Vol. 50, pp. 199-214, 2000.

57) Wang, X., Yu, S. and Huang, G. H. : Land allocation based on integrated GIS-optimization modeling at a watershed level, Landscape and Urban Planning, Vol. 66, pp. 61-74, 2004.

58) Chen, L., Messing, I., Zhang, S., Fu, B. and Ledin, S. : Land use evaluation and scenario analysis towards sustainable planning on the Loess Plateau in China-Case study in a small catchment, CATENA, Vol. 54, pp. 303-316, 2003.

59) Nyeko, M. : GIS and multi-criteria decision analysis for land use resource planning, Geographic Information System, Vol. 4, pp. 341-348, 2012.

60) Aflizar, Saidi, A., Husnain, Ismawardi, Istijono, B., Har- 
mailis, Somura, H., Wakatsuki, T. and Masunaga, T. : A land use planning recommendation for the Sumani watershed, West Sumatra, Indonesia, Tropics, Vol. 19, No. 1, pp. 43-51, 2010.

61) Martin-Mikle, C. J., de Beurs, K. M., Julian, J. P. and Mayer, P. M. : Identifying priority sites for low-impact development (LID) in a mixed-use watershed, Landscape and Urban Planning, Vol. 140, pp. 29-41, 2015.

62) Qiu, Z. : Assessing critical source areas in watersheds for conservation buffer planning and riparian restoration, $E n$ vironmental Management, Vol. 44, pp. 968-980, 2009.

63) Gautam, A. P., Webb, E. L., Shivakoti, G. P. and Zoebisch, M. A. : Land use dynamics and landscape change pattern in a mountain watershed in Nepal, Agriculture, Ecosystems and Environment, Vol. 99, pp. 83-96, 2003.

(Received January 19, 2016) 